\title{
Assessment of Azotobacter chroococcum's Ability to Produce Hydrolytic Enzymes and Enhance Growth of Vicia faba
}

\author{
Hutaf A. A. Alsalim \\ Received 10/4/2018, Accepted 19/12/2018, Published 11/3/2019 \\ This work is licensed under a Creative Commons Attribution 4.0 International License.
}

\begin{abstract}
:
A. chroococcum isolate was examined for its ability to produce the hydrolytic enzymes chitinase, pectinase, protease, and lipase, in an effort to enhance the growth of fava bean (Vicia faba). Biological experiment was conducted in pots with complete random design (CRD). The experiment includes three treatments: control (plant without treatment) (P), NPK fertilizer (plant + fertilizer) (PF), and A. chroococcum inoculum (plant + A. chroococcum) (PA). These treatments were performed with sterile and non-sterile soil, which were planted with fava beans. At the end of experiment (seven weeks from planting), length and weight of plant shoot and plant root were calculated. The results show that the isolate was able to produce chitinase, pectinase, protease, and lipase enzymes. Plant growth increased with fertilizer and A. chroococcum inoculum addition. Fertilizer treatments (PF) were the best growth indicators, with the averages of shoot length and weight, and root length and weight of $19.52 \mathrm{~cm}, 15.55 \mathrm{gm}, 19.93 \mathrm{~cm}$, and $10.52 \mathrm{gm}$ respectively. The averages of these indicators in A. chroococcum treatment (PA) were $16.4 \mathrm{~cm}, 8.85 \mathrm{gm}, 17.52 \mathrm{~cm}$, and $6.88 \mathrm{gm}$ respectively. The percentages of increase caused by A. chroococcum inoculum addition (PA) in contrast with control treatment $(\mathrm{P})$ were $12.83 \%$ and $34.4 \%$ in plant shoot length and weight respectively, and $60.98 \%$ and $38.99 \%$ in plant root length and weight. In general, growth indicators were higher in nonsterile than sterile soil, but these increases were not significant.
\end{abstract}

Key words: Azotobacter chroococcum, Biofertilizer, Fava bean, Hydrolytic enzyme, Plant growth promoting.

\section{Introduction:}

Chemical fertilizers are used to achieve maximum crop production in agricultural fields. The frequent usage of this fertilizers is associated with health hazards, environmental pollution, and loss of soil fertility. Therefore biofertilizers, substances which contain living microorganisms, are gaining importance as they are non-hazardous, ecofriendly and enhance soil fertility. Several bacteria have been used as biofertilizers such as Azotobacter, Azospirillum, Pseudomonas and Rhizobium (1). Azotobacter are aerobic, free-living soil microbes which play an important role in the nitrogen fixation. The isolates of Azotobacter show positive nitrogen fixing capacity ranging from 3.16 to $12.66 \mathrm{mg} \mathrm{N}$ per gram of sucrose consumed (2). Azotobacter have a full range of enzymes needed to perform the nitrogen fixation such as ferredoxin, hydrogenase and an important enzyme nitrogenase (3). Being free living $\mathrm{N}_{2}$-fixer, Azotobacteria synthesize growth materials such as auxins, cytokinins, and gibberellin, which are the primary

Department of Biotechnology, College of Science, University of Baghdad, Baghdad, Iraq.

E-mail: hutafalsalim67@ scbaghdad.edu.iq substances regulating the enhanced growth (4). A. chroococcum has been shown to promote the growth of different crops under different soil types and climates (5). Enzymes are major components of biological soil processes, such as the degradation of organic compounds, mineralization and the liberation or recycling of nutrients (6). Hydrolytic enzymes catalyze the hydrolysis of a chemical bond. There are several types of hydrolytic enzymes such as protease, glucanase, cellulase, pectinase, lipase, and chitinase. Large numbers of soil microorganisms produce lytic enzymes such as Azotobacter, Azospirillum, Bacillus, Pseudomonas, Acetobacter, and fungi (7). The present study was evaluated A. chroococcum as a plant growth promoting bacteria by investigate its ability to produce hydrolytic enzymes and its effect on length and weight of fava beans plant shoot and root.

\section{Materials and Methods:}

\section{Determination Azotobacter ability to produce hydrolytic enzymes}

Chitin, pectin and milk agar-containing plates were inoculated with $24 \mathrm{~h}$ aged bacterial 
cultures (the optical density $=0.84$ at $600 \mathrm{~nm}$ ) and incubated at $30^{\circ} \mathrm{C}$. Formation of a clear zone after incubation time (3-7 days for Chitin, and Pectin, and $24 \mathrm{~h}$ for milk agar) indicated the positive result for production of chitinase, pectinase and protease enzymes respectively $(8,9)$.

Lipase production was investigated on mineral salt olive oil agar, which was inoculated with $24 \mathrm{~h}$ age of bacterial culture and incubated for 3-7 days at $30^{\circ} \mathrm{C}$. Bacterial growth, appearance and reduction of medium oil reflected a positive result (10).

\section{Azotobacter inoculum}

The A. chroococcum isolate used in this study was provided and identified by The Agriculture Research Center of Abu Ghraib (ARC). This bacterium was isolated from the rhizosphere of wheat. Morphologically, it was oval to spherical shape, gram-negative, motile and produced smooth white colonies on nutrient agar. Biochemically, it was positive for oxidase, catalase, urease and indole tests (11). A. chroococcum is reactivated in Burks medium $\left(10 \mathrm{gm} / \mathrm{L}\right.$ Glucose, $0.64 \mathrm{gm} / \mathrm{L} \mathrm{K}_{2} \mathrm{HPO}_{4}$, $0.16 \mathrm{gm} / \mathrm{L} \mathrm{KH} \mathrm{KHO}_{4}, 0.2 \mathrm{gm} / \mathrm{L} \mathrm{NaCl}, 0.2 \mathrm{gm} / \mathrm{L}$ $\mathrm{MgSO}_{4} .7 \mathrm{H}_{2} \mathrm{O}, 0.05 \mathrm{gm} / \mathrm{L} \mathrm{CaSO}_{4} \cdot 2 \mathrm{H}_{2} \mathrm{O}, 0.01 \mathrm{gm} / \mathrm{L}$ $\mathrm{NaMoO}_{4} .2 \mathrm{H}_{2} \mathrm{O}, 0.003 \mathrm{gm} / \mathrm{L} \mathrm{FeSO}_{4}, 1000 \mathrm{ml}$ distilled water, $\mathrm{pH}$ 7) and incubated at $30{ }^{\circ} \mathrm{C}$ for six days (12). Inoculum preparation was achieved by growing of A. chroococcum isolate in $100 \mathrm{ml}$ of the broth culture for six days at $30^{\circ} \mathrm{C}$, where the optical density of bacterial culture was 0.84 at $600 \mathrm{~nm}$.

\section{Plant seeds preparation}

Fava bean (Vicia faba) seeds, which were obtained from ARC, were prepared by surface sterilization using $2 \% \mathrm{HgCl}_{2}$ and $95 \%$ Ethanol for 2 min, and then washed well with distilled water (13).

\section{Soil preparation}

Soil was obtained from Baghdad University fields from the depth of (10-15) cm, and Table (1) showed some of soil properties. Soil was divided into two groups: sterile and non-sterile soil, where the sterile soil was autoclaved three times at $121^{\circ} \mathrm{C}$ for 1 hour each time (14).

Table 1. The properties of study soil.

\begin{tabular}{lc}
\hline \multicolumn{1}{c}{ Properties } & Soil content \\
\hline $\mathrm{pH}$ & 7.3 \\
Electric conductivity $(\mathrm{EC})\left(\mathrm{ds} . \mathrm{m}^{-1}\right)$ & 1.8 \\
Cation exchange capacity $(\mathrm{CEC})$ & 18.6 \\
$\left(\mathrm{cmol} . \mathrm{Kg}^{-1}\right)$ & \\
Organic matter $\left(\mathrm{gm} \cdot \mathrm{Kg}^{-1}\right)$ & 1.4 \\
Nitrogen $\left(\mathrm{mg} \cdot \mathrm{Kg}^{-1}\right)$ & 2.21 \\
Phosphor $\left(\mathrm{mg}^{-1} \mathrm{Kg}^{-1}\right)$ & 14.53 \\
Sand $\left(\mathrm{gm} . \mathrm{Kg}^{-1}\right)$ & 233 \\
Silt $\left(\mathrm{gm} \cdot \mathrm{Kg}^{-1}\right)$ & 273 \\
Clay $\left(\mathrm{gm} \cdot \mathrm{Kg}^{-1}\right)$ & 494 \\
Texture & Sandy loam \\
\hline
\end{tabular}

\section{Biological experiment}

Sterile and non-sterile soil was distributed in 18 sterile, $5 \mathrm{Kg}$ pots, 9 for each set of trials. Seeds, treated with inoculum, were soaked with $100 \mathrm{ml}$ of A. chroococcum fresh culture (the optical density $=0.84$ at $600 \mathrm{~nm}$ ) and mixed with sterilized Arabic gum. NPK fertilizer supplied by ARC.

Biological experiment performed (CRD) with three replicates and two factors; sterile and non-sterile soil and three treatments: control, include plant without treatment $(\mathrm{P})$, NPK fertilizer $\left(100 \mathrm{Kg}\right.$. hec. $\left.{ }^{-1}\right)$ (PF), and addition of $A$. chroococcum inoculum (PA). Thus there were 18 experimental units $(2 * 3 * 3=18)$. Seeds were cultured, pots were arranged randomly inside a plastic house and irrigated with tap water.

\section{Plant growth promoting effect estimation}

Seven weeks after germination, an assessment of length and weight of each plant shoot and plant root were conducted.

\section{Statistical Analysis}

The experiment was statistically analyzed using ANOVA, and the averages was compared with least significant difference (LSD) values at the level of 0.05 (15).

\section{Results and Discussion:}

\section{A. chroococcum ability to produce hydrolytic enzymes}

A. chroococcum isolate was able to form hydrolytic zones on chitin, pectin and milk agar (Table 2), so it was able to produce chitinase, pectinase and protease enzymes ( 8 and 9 ). The isolate also was able to grow and reduced the oil in mineral salt olive oil agar, verifying the ability to produce a functional lipase enzyme (16). Production of hydrolytic enzymes including cellulose, pectinase, protease, chitinase and lipase by some rhizospheric bacterial community indicate its benefit and plant growth promoting activity (17). Rodrigues and his team (18) isolated 136 sugarcane associated bacteria, of them 83 were presenting some plant growth mechanism: $47 \%$ phosphate solubilizers, $26 \%$ nitrogen fixers and $57 \%$ producing IAA, $0.7 \% \mathrm{HCN}$ and chitinase, $45 \%$ ammonia, $30 \%$ cellulose and $8 \%$ pectinase. They found that best isolates, which belong to the Enterobacteriaceae family and the

Klebsiella, Enterobacter and Pantoea genera, promoted maize plant growth in greenhouse experiments. 
Table 2. Hydrolytic enzymes produce by $A$. chroococcum isolate.

\begin{tabular}{cc}
\hline Enzymes & $\begin{array}{c}\text { Production ability (Diameter of clear } \\
\text { zone }(\mathbf{m m}))\end{array}$ \\
\hline chitinase & $+(3.7)$ \\
pectinase & $+(4.5)$ \\
protease & + \\
lipase & + \\
\hline
\end{tabular}

\section{Azotobacter chroococcum inoculum effect on plant shoot \\ -Shoot length}

The average shoot length of fava bean in non-sterile soil treatments $(17.02 \mathrm{~cm})$ was more than in sterile soil treatments $(16.61 \mathrm{~cm})$, but this difference is not significant. Azotobacter inoculum increased shoot length in sterile and non-sterile soil (Figs. 1 and 2).

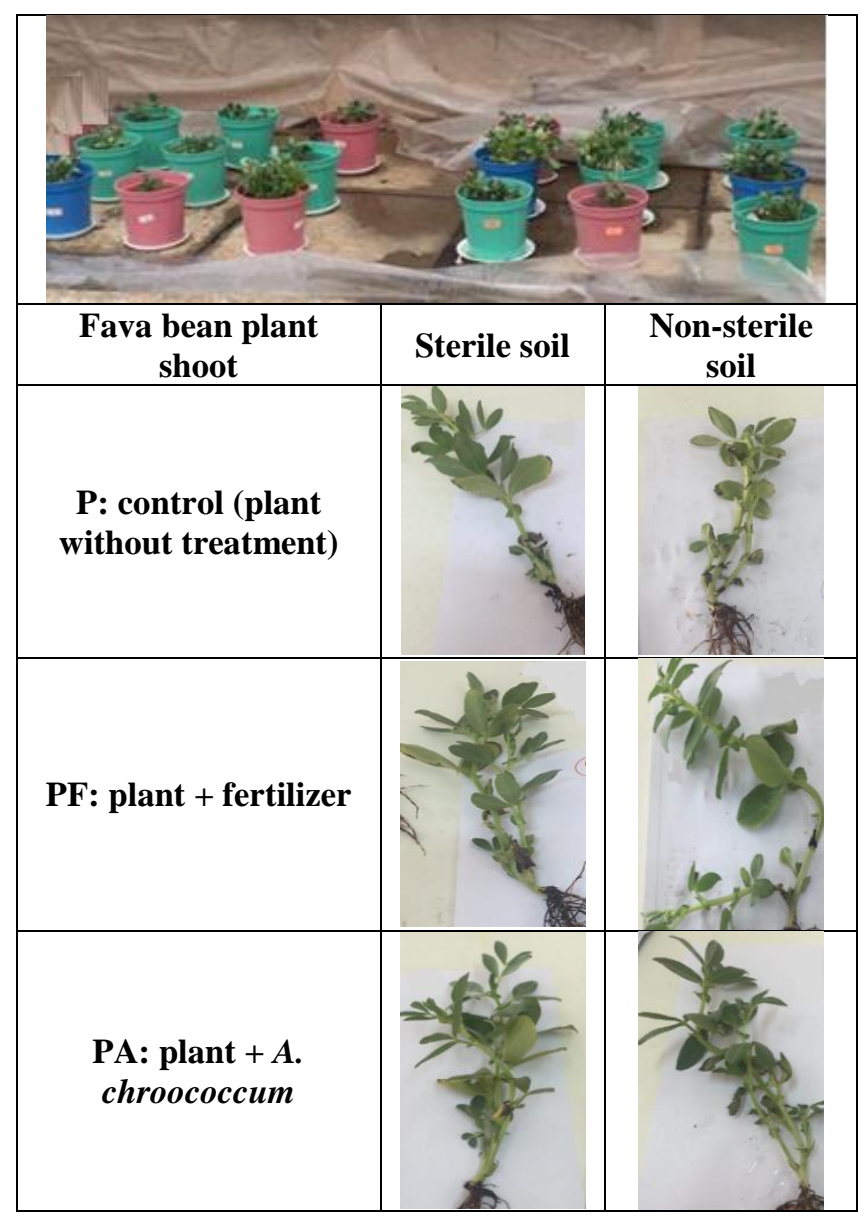

Figure 1. Fava bean shoot in the treatments: $P$ : control (plant without treatment), PF: plant + fertilizer, and PA: plant $+A$. chroococcum.

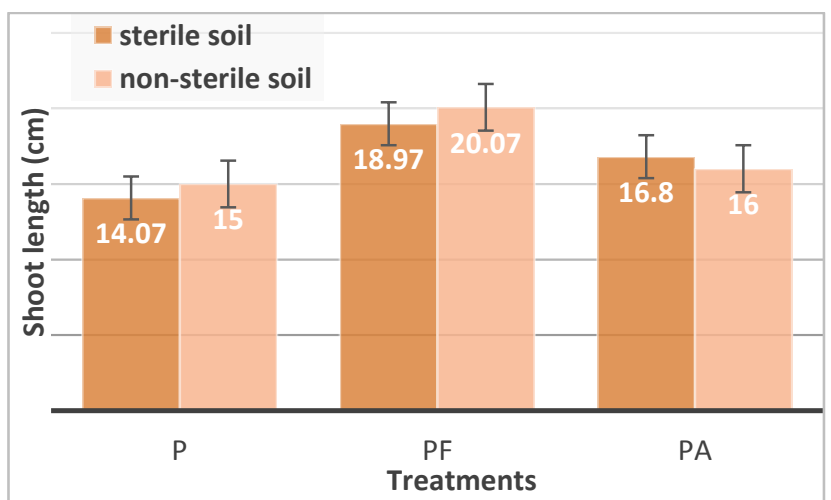

Figure 2. Fava bean shoot length $(\mathrm{cm})$. The treatments: P: control (plant without treatment), PF: plant + fertilizer, and PA: plant $+A$. chroococcum. $\left(\mathrm{LSD}_{0.05}=3.64\right)(\mathrm{SE}=1.180)$.

The percentage of increase caused by Azotobacter inoculum addition was $12.83 \%$. Fertilizer treatments show significant increase in shoot length from control treatments. There were no significant differences between fertilizer treatment $(18.97 \mathrm{~cm})$ and Azotobacter treatment $(16.8 \mathrm{~cm})$ in sterile soil. While these two treatments (20.07 and $16 \mathrm{~cm}$ respectively) exhibited significant differences in non-sterile soil, this may have related to the computation of indigenous microorganisms. Azotobacter inoculum increased the growth by supplying the crop with nitrogen through asymbiotically fixation and phytohormone synthesis. Kalay and his team (19) mention that applying A. chroococcum on choy sum (Brassica rapa L.) did not increase the yield. Felipe and his team (5) observed a beneficial effect on greenhouse planted cotton inoculated with A. chroococcum, and suggested that co-inoculation allow to reduce nitrogen fertilization doses up to $50 \%$.

\section{Shoot weight}

There were no significant differences between the averages of plants shoot weight in sterile soil treatments $(10.09 \mathrm{gm})$ and non-sterile soil treatments $(10.56 \mathrm{gm})$. Fertilizer treatments (15.03 and $16.07 \mathrm{gm}$ respectively) showed significant increase in shoot weight from the control (6.92 and $6.25 \mathrm{gm}$ respectively) and Azotobacter treatments (8.33 and 9.37 gm respectively) (Fig. 3). Shoot weight gained increase by $34.4 \%$ in Azotobacter treatment compared with control treatment, which may have been related to production of indol-3-acetic acid and siderophores, which can increase nutrient availability and improve plant growth (20). Felipe and his team (5) evidenced an increase ranging between 8 and 53\% in all parameters of plant growth, suggesting that A. chroococcum inoculation has a higher potential to promote cotton plant growth. 


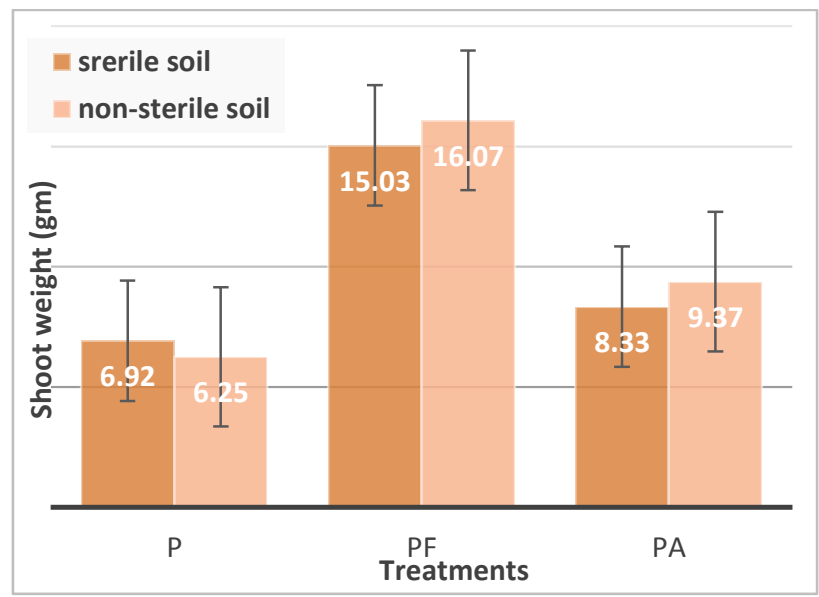

Figure 3. Fava bean shoot weight (gm). The treatments: P: control (plant without treatment), PF: plant + fertilizer, and PA: plant $+A$. chroococcum. $\left(\mathrm{LSD}_{0.05}=4.41\right)(\mathrm{SE}=1.431)$.

\section{Azotobacter chroococcum inoculum effect on plant root \\ -Root length}

The results in figs. (4 and 5) show that fertilizer treatments exhibited highest length of bean plant root in non-sterile and sterile soil (19.6 and $20.26 \mathrm{~cm}$ respectively) followed by Azotobacter treatments (16.6 and $18.43 \mathrm{~cm}$ respectively). Azotobacter inoculum increased the length of plant roots in contrast with control treatments, with an increase of $60.98 \%$. Root lengths in non-sterile soil $(16.85 \mathrm{~cm})$ are improved better than in sterile soil $(15.37 \mathrm{~cm})$. Wani Sartaj and his team (21) mentioned that Azotobacteria affect the growth of the closely associated higher plants. They can benefit plant development through multiple mechanisms of action, directly through the production of substances which promote growth and increase nutrient availability in soil and their uptake, or indirectly through the suppression of plant pathogens (20).

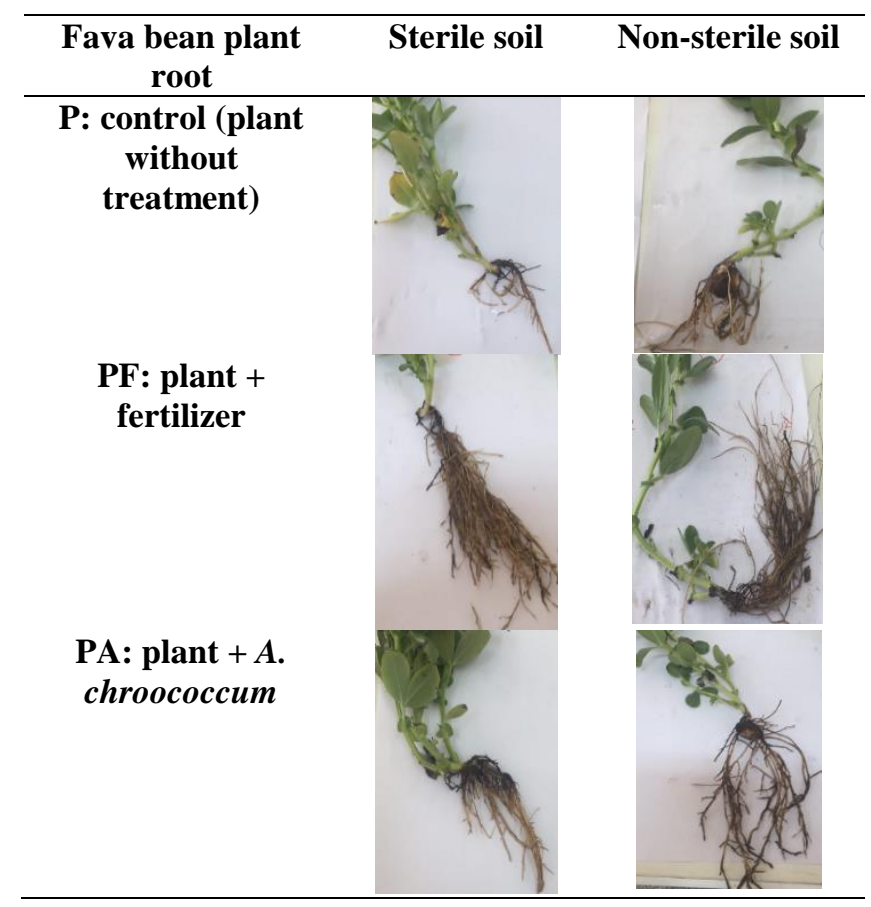

Figure 4. Fava bean root in the treatments: $P$ : control (plant without treatment), PF: plant + fertilizer, and PA: plant $+A$. chroococcum .

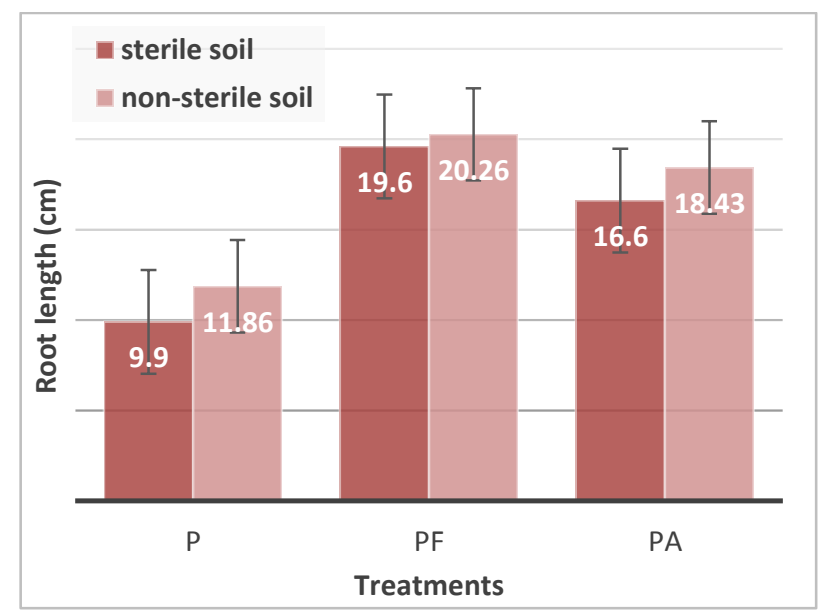

Figure 5. Fava bean root length $(\mathrm{cm})$. The treatments: P: control (plant without treatment), PF: plant + fertilizer, and PA: plant $+A$. chroococcum. $\left(\mathrm{LSD}_{0.05}=9.4\right)(\mathrm{SE}=3.049)$.

\section{Root weight}

The treatments of non-sterile soil presented no significant increase in the average of fava bean plants root weight $(8.05 \mathrm{gm})$ from sterile soil treatments $(6.84 \mathrm{gm})$. Fertilizer treatments obtained maximum root weight in sterile soil and non-sterile soil (10 and $11.03 \mathrm{gm}$ respectively), which differ significantly other treatments (fig. 6). Azotobacter inoculum enhanced the roots weight of bean plant in sterile soil and non-sterile soil by 6.13 and $7.63 \mathrm{gm}$ respectively. The percentage of increase in inoculum treatments from control treatments was $38.99 \%$. This increase may have been related to synthesized hormonal substances 
which originate from the rhizosphere or root surface (21). Tiwari and his team (1) reported that Azotobacter sp. inoculum enhanced plant shoot length, root length, leaves number, shoot and root fresh and dry biomass, but mixed inoculations of Rhizobium sp. and Azotobacter sp. revealed further enhancement.

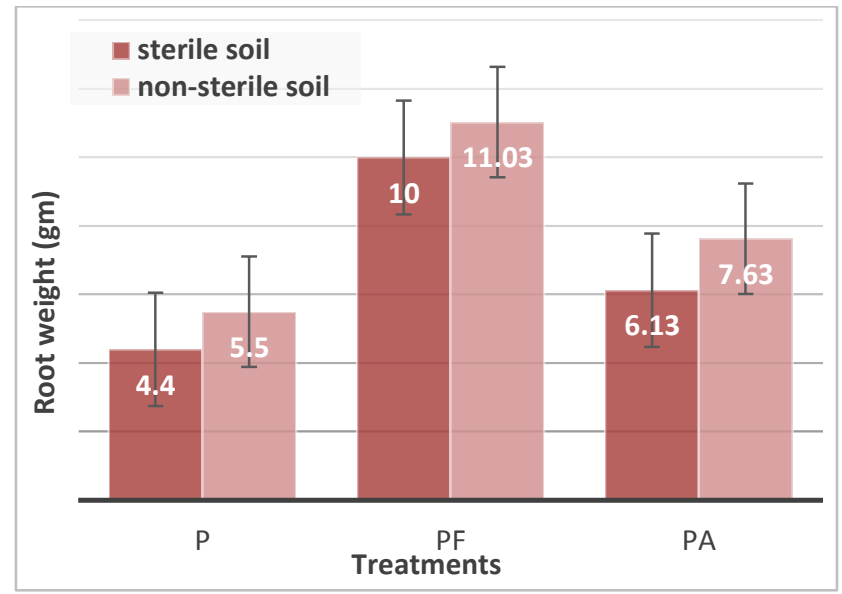

Figure 6. Fava bean root weight (gm). The treatments: P: control (plant without treatment), PF: plant + fertilizer, and PA: plant $+A$. chroococcum. $\left(\mathrm{LSD}_{0.05}=2.58\right)(\mathrm{SE}=\mathbf{0 . 8 5 6})$.

\section{Conclusion:}

The concept of this study is to use natural alternatives that are effective and not harmful to the environment. Therefore, A. chroococcum isolate, which is known for its capability to fix atmospheric nitrogen, was used. Moreover, Azotobacter strains have been well known for their siderophores, indol3-acetic acid and exopolysaccharides (EPS) production, which may benefit plant growth/nutrient availability and soil water retention properties. This isolate was also able to produce chitinease, pectinase, protease and lipase enzymes. $A$. chroococcum isolate improved length and weight of fava bean plants shoot and root. Therefore, such addition should be recommended to replace chemical fertilizers, albeit partially, in order to reduce the risk of chemical toxicity and preserve soil fertility and health.

\section{Conflicts of interest: None}

\section{References:}

1. Tiwari S, Chauhan RK, Singh R, Shukla R, Gaur R. Integrated Effect of Rhizobium and Azotobacter Cultures on the Leguminous Crop Black Gram (Vigna mungo). Adv in Crop Sci and Tech. 2017; 5 (3): 1-9.

2. Bag PB, Panda P, Paramanik B, Mahato B , Choudhury A. Atmospheric Nitrogen Fixing Capacity of Azotobacter Isolate from Cooch Behar and
Jalpaiguri Districts Soil of West Bengal, India. Int. J. Curr. Microbiol App. Sci. 2017; 6 (3): 1775-1788.

3. Amutha R., Karunakaran S., Dhanasekaran S., Hemalatha K., Monika R., Shanmugapriya P, et.al.. Isolation and mass production of biofertilizer (Azotobacter and Phosphobacter). International J. of Latest Res in Sci and Tech. 2014; 3: 79-81.

4. Satai A,Wani, S C, Muneeb A, Wani, MR, Khalid R H. Azotobacter chroococcum- A potential biofertilizer in agriculture: an overview. Soil Sci: Agric Env Prospectives.2016; 333-348.

5. Felipe RP, Abril J, Camelo M, Galván AM, Tapias DR, Bonilla R. Azotobacter chroococcum as a potentially useful bacterial biofertilizer for cotton (Gossypium hirsutum): Effect in reducing N fertilization. Rev Arg de Microb. 2017; 49: 377-383.

6. Baldrian P. Chapter 2 Enzymes of saprotrophic Basidiomycetes. British Mycological Society Symposia Series. 2008; 28: 19-41.

7. Emimol A., Ganga G, Parvathy R, Radhika G, Nair GM. Screening of microbes producing extracellular hydrolytic enzyme from corporation waste dumping site and house hold waste for the enhancement of bioremediation methods. IOSR J. of Pharm Bio Sci. 2012; 4:54-60.

8. Sampson M N, Gooday GW. Involvement of chitinease of Bacillus thuringiensis during pathogenesis in insects. Microbiology. 1998; 144: 2189-2194

9. Harrigan W F, MacCance ME. Laboratory methods in food and diary microbiology. 1979; Academic press. New York.

10. Ghafil JA, Hassan SS. Effect of cultural conditions on lipase production from Pseudomonas aeruginosa isolated from Iraqi soil. World J Exp Biosci. 2014; 2: $13-18$

11. Williams ST, Sharpe ME, Holt JG. Bergey's Manual of Systematic Bacteriology. Baltimore, USA: Williams and Wilkins; 1984.

12. Pozo C, Martinez-Toledo M.V, Rodelas, B., Gonzalez L J. Effect of culture conditions on the production of polyhydroxyalkanoates by Azotobacter chroococcum $\mathrm{H} 23$ in media containing a high concentration of alpechin (wastewater from olive oil mills) as primary carbon sources. J. Biotech. 2002; 97(2): 125- 131.

13. Vincent JM. A manual for the practical study of rootnodules bacteria. International Biological Program. Handbook No.15. Black well Scientific Publication. Oxford, England. 1970; 125 - 126

14. Bashan Y, Puente ME, Mendoza MNR, Toledo G, Holguin G, Cerrato RF Pedrin S. Survival of Azospirillum brasilense in the bulk soil and rhizosphere of 23 soil types. App and Environmental Microb.1995; 16 (5): 1938 -1945

15. SAS. Statistical Analysis System, User's Guide. Statistical. Version 9. $1^{\text {th }}$ ed. SAS. Inst. Inc. Cary. N.C. USA. 2012.

16. Singh M.K, Singh HB, Prabha R. Microbial inoculants in sustainable agricultural productivity. Springer, India. 2016; 229-244.

17. Naseer A, Shinwari ZK, Bashir S Yasir M. Function and polygenetic characterization of rhizospheric 
bacteria associated with GM, and non GM maize. Park J. Bot. 2013; 45(5): 1781-1788.

18. Rodrigues AA, Forzani MV, Soares RS, Sibov ST, and Vieira JDG. Isolation and selection of plant growth-promoting bacteria associated with sugarcane. Pesqui Agropecu Trop. 2016; 46 (2):1983-4063.

19. Kalay AM, Hindersah R, Talahaturuson A, Latupapua AI. Dual inoculation of Azotobacter chroococcum and Trichoderma harzianum to control leaf blight (Rhizoctonia solani) and increase yield of choy sum. International J. of Scientific \& Engineering. 2017; 8: 1288- 1292 .
20. Viscardi S, Ventorino V, Duran P, Maggio A, De Pascale S, Mora ML,et.al.. Aossessment of plant growth promoting activities and abiotic stress tolerance of Azotobacter chroococcum strains for a potential use in sustainable agriculture. J. Soil Sci. Plant Nutr. 2016; 16 (3): 848-863.

21. Wani Sartaj A, Subhash Chand, Tahir Ali. Ptential use of Azotobacter chroococcum in crop production: An overview. Curr. Agriculture Res. J. 2013; 1 (1): 35-38.

\title{
تقييم قدرة بكتريا Azotobacter chroococcum في انتاج الانزيمات الحالة وتحسين نمو الباقلاء (Vicia faba)
}

\author{
هتاف عبدالملك احمد السالم
}

قسم التقتيات الإحيائية، كلية العلوم، جامعة بغداد، بغداد، العر اق

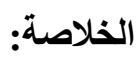

اختبرت قدرة عزلة الآزوتوباكتر Azotobacter chroococcum في إنتاج الانزيمات الحالة (الكايتينيز و البكتينيز و البروتيز

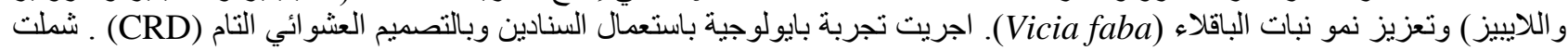

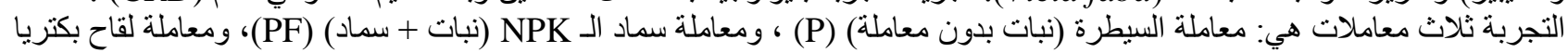

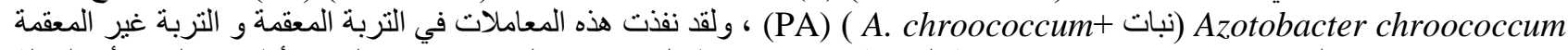

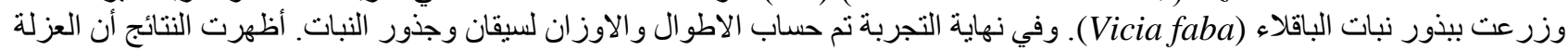

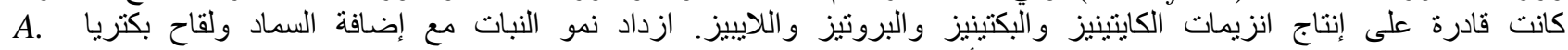

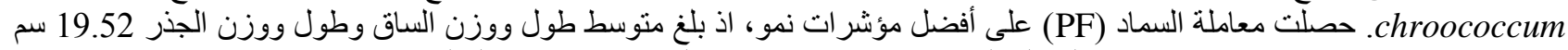

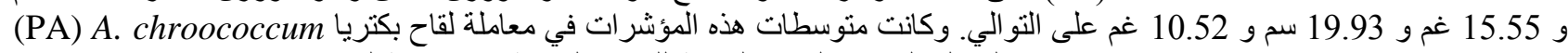

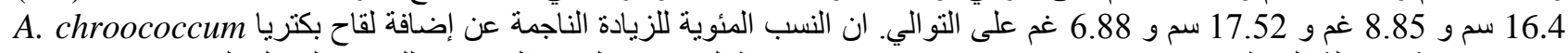

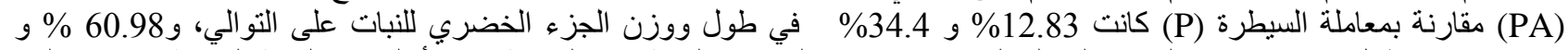

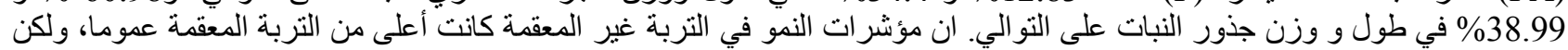
هذه الزيادات لم تكن معنوية. الكلمات المفتاحية: Azotobacter chroococcum ، المخصب الحيوي، الباقلاء، الانزيمات الحالة، تعزيز نمو النبات. 